\title{
教育費支出の動機構造の解明にむけて
}

——教育意識の決定木分析——

古田 和久

\section{1. 問題設定}

教育経済学の研究では, 家計の教育費負担に関して，2つの解釈が提示されてき た。1つは，教育を投資とみなす見方である。つまり，人的資本論では，教育が生 産能力や賃金を高めるための投資として捉えられ，費用と便益を比較することによ って, 教育需要が決定されると想定する。こうした見方は, 教育社会学にも存在す る。そこでは, 教育を通じた地位達成に関する研究が蓄積され, 社会移動や職業的 地位達成における教育の役割に焦点をあててきた。いずれにしても, 投資としての 見方では，教育が高い社会的地位や所得を得るための手段として捉えられるために， 人びとが教育を求めると考える。

もう 1 つは，教育を消費として捉える見方である。教育の消費的側面は，教育を 受けること自体から得られる満足を意味する。そして, 消費の主体には, 親と子ど もが想定されるが，特に教育を受けさせる親の行動として，この面が強調されてい る（小塩 1999）。また, 教育社会学においても投資としての地位形成機能に対し て, 地位表示機能が区別されている。地位表示機能とは, 人びとの㷌属している地 位の指標として教育を捉えるものであり，消費としての性格が強いとされる（天野 1983)。この観点から教育需要を考えれば, 人びとが自身の地位に応じた教育を求 め, それによって満足を得るということになる。

以上のような投資と消費が，家計の教育費負担に関する主要な見方であるが，末 冨（2005）は，これらに贈与を付け加え，親の教育費投入動機に迫っている。高校

大阪大学大学院 
生，大学生の親の質問紙調査を分析した結果，親のなかには投資，消費，贈与のす べてから得られる便益を求める者がいる一方で, どの便益にも関心を示さない者も いるなど，単純な投資や消費では捉えられない，多様な教育費投入動機があること を指摘している。

この末冨（2005）の議論が, 投資, 消費, 贈与を基本として, 親の意識パターン から，教育費投入動機を解明しようとする試みであるように，どんな場合に，投資 や消費などの側面が重視されるのかをパターン化して示すことができれば, 教育費 支出の動機構造を読み解くことにつながるだろう。例えば, 親の社会的特徵や社会 状況の認識によって, 重視する側面がまったく異なる可能性は十分にある。高所得 層の親は，消費的色彩の強い地位表示機能を意図して教育を求めるのに対して，低 所得層の親は，投資的側面を重視しているかもしれない。

同じように，社会や教育の現状をどう認識しているかによっても，投資や消費の どちらの側面を重視するかが異なってくるはずである。例えば，Ball (2003) は，近 年の経済状況の不安定化が，ミドルクラスの親に社会的再生産に対する不安を生じ させ，それが子どもの教育に対する関心となって現れるとする。この指摘は，現在 の社会経済状況が不安定であると認識している者は, 地位形成機能を重視する可能 性が大きいことを示唆する。また，日本では不公平感の中でも，学歴による不公平 感が高いが（原・盛山 1999）, 学歴不公平感の強い人は, 自身の子どもが有利な立 場につける（学歴によって不利な状況に陥らない）ように，投資的側面から教育費 を負担するということもあり得る。

さらに，教育機会の認識も密接に関わっている。苅谷（1995）によれば，日本は 学歴社会であるという人びとの認識が，「大衆教育社会」の成立において重要な役割 を果たした。その認識は, 学歴による差別に目を向けさせる一方で, 学歴取得に関 しては, 教育の機会均等と競争の公正さを強調する平等観を含んだものであった。 すなわち, 学歴社会という認識は, 学歴の投資的側面を重視するとともに, 教育機 会は開かれているという状況認識を前提としたものである。こうした認識によって, 人びとが「教育熱」と呼ばれるほどに学歴を求めたとすれば，教育機会の認識も考 慮することで，より現実的な教育費負担動機を示すことができるだろう。

実際，中村（2000）は，学歴取得後の効用と学歴取得機会に関する認識を組み合 わせることによって, 社会移動構造の認知を類型化し, 社会移動構造の認識と学歴 志向の関連を検討している ${ }^{(1)}$ 。その結果, 若年層では, 出身家庭による教育機会の閉 鎖性を認識した者が高学歴志向になりやすいことを報告しており, 教育需要が社会 
状況の認識に依存することを具体的に示している。

以上のように, 教育を求める動機は, さまざまな要因によって複雑に形成されて いると考えられる。こうした複雑な関係を考慮したうえで，どんな場合に，投資や 消費などの側面が重視されるのかをパターン化し, 子どもへの教育費支出の動機を 読み解こうとすれば, 雑多な変数を一括して分析できる, 探索的な手法が必要であ る。

データマイニングの手法として知られる決定木 (decision tree) は, この要求を 満たす方法である。すなわち決定木とは，データを探索的に分析し，変数間の関連 を発見するものである。より具体的に言えば，サンプルを繰り返しサブグループに 分割し, それぞれのサブグループにおいて, 従属変数に対して最も影響力の強い変 数を探し出す手法である。このため，条件付き効果を発見することができるという 利点がある（Thomas and Galambos 2004，近藤ほか 2005, Billari et al. 2006)。 よって，決定木を利用すれば，どんな意識や属性を持った者が，投資的側面や消費 的側面を重視して教育を求めるのかを明らかにすることができる ${ }^{(2)}$ 。また, 後述する ように，変数間のパターンをノードと枝によって明確に示し，教育費負担に意欲的 な者とそうではない者を区別する経路を描くため，より解釈がしやすいという特長 もある。このような点から，決定木は教育意識の分析にふさわしいと考える。

本論では，投資や消費に関する意識だけではなく，教育機会の認識など，多くの 変数を同時に分析し，いかにして教育費負担に意欲的な者とそうではない者の意識 が分化していくかを，決定木を用いて検討する。その作業を通して，変数間の関連 を捉え，そこに現れたパターンから教育費負担の主観的意味を読み取るのが，以下 の課題である。

\section{2. データと変数}

分析に用いるデータは，「2003年仕事と暮らしに関する全国調査」である。この調 査は,「2005年社会階層と社会移動調査 (SSM 調査)」の予備調査として位置づけら れ, 日本全国に居住する20歳から69歳の男女を母集団として, 層化 2 段無作為抽出 法によって抽出された個人を対象に，2003年12月に行われた。計画サンプル数は 2 , 000, そのうち有効回収数は 1,154 , 有効回収率は $57.7 \%$ であた。質問項目には, 回答者の学歴, 職業や所得といった社会階層に関する変数とともに, 数多くの意識 項目が含まれている(2003年階層調査研究会 2004)。なお, 分析に用いるのは, 全 サンプルから従属変数に欠損值を持つサンプルを除いた 1,125 ケースである。 
表 1 分析に用いた変数

\begin{tabular}{|c|c|}
\hline 客観的 & \\
\hline $\begin{array}{l}\text { 基本的属性 } \\
\text { 性別 } \\
\text { 年齢 } \\
\text { 結婚 }\end{array}$ & $\begin{array}{l}\text { 男, 女 } \\
20 \text { 歳から } 70 \text { 歳 } \\
\text { 結婚経験あり (既婚, 死別, 離別), 結婚経験なし (未婚) }\end{array}$ \\
\hline $\begin{array}{l}\text { 階層変数 } \\
\text { 学歴 } \\
\text { 職業 } \\
\text { 世帯年収 } \\
\text { 所有財 }\end{array}$ & $\begin{array}{l}\text { 中学, 高校, 高等（短大・高専, 専修学校, 大学, 大学院) } \\
\text { 専門管理, 事務販売, ブルーカラー, 無職 } \\
\text { 過去一年間の生計をともにしている家族の税込み収入 } \\
\text { 18項目の財の所有状況を得点化 }\end{array}$ \\
\hline \multicolumn{2}{|l|}{ 意識変数 } \\
\hline $\begin{array}{l}\text { 投資 } \\
\text { 大卒便益 } \\
\text { 学歴収入 }\end{array}$ & $\begin{array}{l}\text { よい大学を出ることが，高い地位や収入を得るために不可欠だ。 } \\
\text { 学歴の高い人ほど高い収入を得ている。 }\end{array}$ \\
\hline $\begin{array}{l}\text { 消費 } \\
\text { 階層帰属 }\end{array}$ & $\begin{array}{l}\text { 仮に現在の日本の社会全体を，5つの層に分けるとすれば，「上」,「中の上」, } \\
\lceil\text { 「の下,「下の上」,「下の下」(のうちいずれか) に入る。 }\end{array}$ \\
\hline 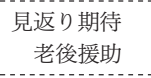 & 老後を過ごすために，子どもや親族からの経済的援助をあてにしている。 \\
\hline $\begin{array}{l}\text { 社会状況認識 } \\
\text { 機会平等 } \\
\text { 学歴不公平 } \\
\text { 達成機会 } \\
\text { 大企業安定 } \\
\text { 経済不安定 }\end{array}$ & $\begin{array}{l}\text { 大学教育を受ける機会は, 貧富の差に関係なく平等に与えられている。 } \\
\text { 学歷による不公平が, 今の日本社会にある。 } \\
\text { 高い地位や収入を得る機会は豊富にある。 } \\
\text { 大企業に就職しさえすれば, 豊かで安定した生活を送ることができる。 } \\
\text { 経済的に安定した生活を送るために何が必要かが, わからない世の中になった。 }\end{array}$ \\
\hline \multicolumn{2}{|c|}{ 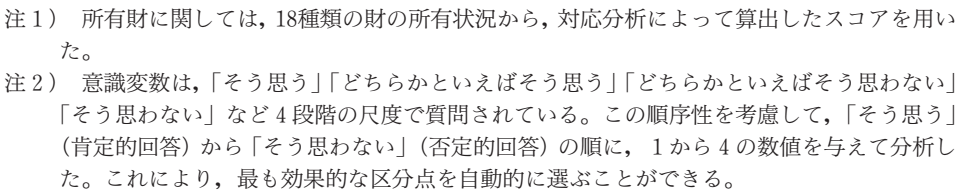 } \\
\hline
\end{tabular}

まず，従属変数は子どもの教育費負担に対する親としての意識である。教育需要 の主体には，教育を受ける子どもと，教育を受けさせる親が区別されるが（小塩 2002), 多くの場合, 教育費負担を担っているのは親であるから，ここでは後者の意 識に注目する。この調査では, 子どもの学校・塾・予備校などの学費について, 2 つの意見を対比させ，どちらの意見に近いかを質問している。具体的には，「親が子 ぞもの希望する教育のための費用を，全額負担するのは当然である(A)」,「親が子ど もの学費を負担するのは一定の範囲までであり, それ以上の費用は子ども自身で負 担すべきだ(B)」という 2 つ意見について，「A に近い」から「B に近い」までの 5 段階の尺度で, 子どもの教育に対する態度を尋ねている ${ }^{(3)}$ 。こうして, 親の教育費負 担意識を, 子どもの教育費支出に対する負担意欲の強さから捉えている。つまり, 
「Aに近い」は，何とかして子どもの教育費を工面しようとする強い態度であるのに 対して，「Bに近い」であれば，親自身が負担しようとする意欲が相対的に弱いと解 釈される。また，そうした意識と，以下で示す諸変数との関連が明らかにできれば, どのような動機が負担意識の強さと結びつき，あるいは結びつかないのかを明らか にすることができるだろう。ここでは，これまで指摘されてきたような親の積極性 に着目して，「Aに近い」を「親全額」，「ややAに近い」「どちらともいえない」「や や Bに近い」「Bに近い」を「それ以外」とした。

また, 表 1 には, 独立変数を示している。これらは, 客観的変数と意識変数の 2 つに大別され, 客観的変数には, 性別, 年齢, 結婚経験と階層変数が含まれる。例 えば，Bourdieu（訳書 1990）は，教育投資に対する意図が明確なのはプチブルと 呼ばれる中間階級であることを示唆しているが，こうした関係があれば，学歴や職 業によって教育費負担意識の傾向が大きく異なると予想される。

一方で，意識変数にはたくさんの項目が含まれる。まず，投資的側面の意識は， 社会的地位や所得という, 大卒学歴の便益に関する認識である。すなわち, 大卒学 歴の便益を肯定しており，同時に教育費負担の意欲も強ければ，投資的意識が優勢 であるとみなすことができる。また，「学歴収入」は学歴の高い人ほど高い収入を得 ているという状況に対する評価であり，「好ましい」から「好ましくない」までの 4 段階の選択肢で尋ねている。次に, 消費的側面として階層帰属意識を用いる。この 変数を用いるのは, 階層構造上に拄ける自身の地位に対する認識に応じて, 教育に 対する意識が異なっているとすれば，地位を示すための消費的色彩が強いと考える ことができるからである。さらに，老後の収入に関する意識を加えた。子どもの利 益を考えて教育費を投入する場合と，親自身の利益のために負担する場合があるが (末冨 2005), 教育費負担に対する態度と, 老後の援助とに関連が見られれば, 見 返りを期待して，子どもの教育にお金をかけているかどうかを捉えることができる。 最後に, 社会状況の認識として, 教育機会に関する認識と学歴不公平感, 地位達成 と経済状況に関する認識を用いる。こうした教育や社会に関する認識を用いること で, 状況の認識によって, 教育費負担動機が異なるかどうかを検討する。次に, こ のような多様な変数群を投入してパターンを探る方法である決定木を簡単に紹介し, 分析を行う。 


\section{3. 分析}

\section{1. 方法}

本論では，意識変数間のパターンを抽出するために，データマイニングの分野で 用いられる決定木を利用する。データマイニングとは，コンピュータやネットワー クなどの情報技術の発展を背景として, 近年マーケティングなどの分野を中心に注 目を集めている領域であり，大量のデータから意味のあるパターンを発見すること を指す。データマイニングの手法として，多くの分析手法が紹介されているが，そ の中でも決定木は，膨大なデー夕からモデルを帰納的に構築し，樹木のように枝を 分岐させて表現する方法である。これによって，従属変数とたくさんの独立変数と の関係を探ることができるのである（豊田 2001，Berry and Linoff 訳書，2005）。

下の分析が示すように，決定木はノードとして選ばれた変数の值によって，全サ ンプルを繰り返し，サブグループに分割していく方法である。したがって，どの変 数で，サンプルを分割するかの決定が重要となる。つまり，ノードに選ばれる変数 が異なれば，生成される決定木もまったく異なったものになるのである。この方法 の利点の 1 つ, 離散変数, 連続変数に関係なく, 雑多な独立変数を一括して投入で きることにあるが，そうした多くの変数の中から，分割に用いる変数を選ぶ基準は， ノードにおける純度（purity）の増加である。すなわち，投入された各変数によっ て，サブグループに分割したときに，従属変数の 1 つの值が，一方の方向により多 く集中する変数で分割がなされる ${ }^{(4)}$ 。このように,たくさんの変数を投入するにもか かわらず，生成された決定木は，教育費負担に意欲的な者とそうではない者を分け る諸変数と, それらのパターンを簡潔に表現する。加えて, 変数間のパターンをた どれば，どんな場合に投資や消費などの側面が現れるのかを示すことができ，解釈 がしやすい。複雑な教育費負担動機を読み解くうえで, こうした決定木の特徴はた いへん有益である。

\section{2. 決定木によるパターン抽出}

決定木による分析を行う前に，従属変数の分布を見ておく。「Aに近い」とする人 は半数近くに上り $(47.2 \%)$, さらに「やや $\mathrm{A} に$ 近い」は $16.5 \%$ であから，親の全 額負担を当然とする見方に偏っており，「教育熱」が根強く存在することが確認でき る。一方で,「Bに近い」と「やや B に近い」は合わせて 3 割程度である。

こうした全体の傾向は，親が子どもの教育費を負担すべきという意見が多いこと 
を示しているが，ここでは，「Aに近い」を「親全額」，「やや $\mathrm{A} に$ 近い」「どちらと もいえない」「やや B に近い」「Bに近い」を「それ以外」とし， 2 值変数に変換し た。次に，この意識の分化にどのような要因が関連しているかを探っていくことに する。

図 1 は, 教育費負担意識を基準として, 表 1 のすべての変数を投入し, 決定木分 析を行った結果である。眓の見方は次のとおりである。まず，楕円で囲まれている 変数はノード (node) と呼ばれ, その中でも, 特に一番上に現れるノードを根(root) と呼ぶ。根に現れる変数は, 従属変数を分類するうえで, 最も影響力の強い変数で あるということを意味する。これまでの教育意識研究では, 便益の認識に注目が集 められていたが，社会状況の認識や社会的特徵による違いはなく，投資の側面が最 も重視されているとすれば，それを示す変数（「大卒便益」，「学歴収入」）が根ノー ドに現れることになる。

決定木の分類は，根から始まり，各ノードがとる值にしたがって，枝（branch） に分岐し，最終的に四角で囲まれた葉（leaf）に至る。こうして全体のサンプルを， ノードに現れる変数の值によって，矢印（枝）の方向に，次々にサブグループに分 割していくのである。決定木の末端の葉には, 従属変数がとる值とそこに分類され たケース数が示されている。例えば，葉のラベルが「親全額」（168.3/53.3）の場 合，168.3人がその葉に分類されたが， 53.3 人は従属変数の值が，「親全額」ではな いにもかかわらず，誤ってこの葉に分類されたことを示す（168.3-53.3=115ケー スは正確に分類されたということである)。なお，ケース数には小数点以下の值もあ るが,これはノードの変数に欠損值があるケースの場合，1ケースを例えば 0.5 ケ スずつ各枝に分割する，といった計算を行うからである。

また，分析に投入したにもかかわらず，決定木にまったく現れない変数もある。 その変数は, ノードを生成するどの局面においても, 従属変数との関連がないか, あるいはそれほど強くないということである。したがって, 最終的に作られた決定 木によって, 従属変数を予測する際には, まったく考慮されないことを意味する ${ }^{(5)}$ 。

図 1 を見ると, 教育費負担意識を分類するのに最重要な変数は, 教育機会の認 識である。つまり, 貧富の差に関係なく大学教育を受ける機会が平等に与えられて いると認識しているケースは，左の枝に進む。左の枝に進んだ場合，次に「所有財」 が現れる。この変数は家庭の財の所有状況をもとに, 現在の経済状態を指標化した ものであり，スコアが大きいほど豊かであることを示す。このノードでの分岐を見 ると, 比較的豊かであると親が全額負担を当然とみなすことが分かる。逆に，スコ 
図 1 教育費負担意識を基準とした決定木

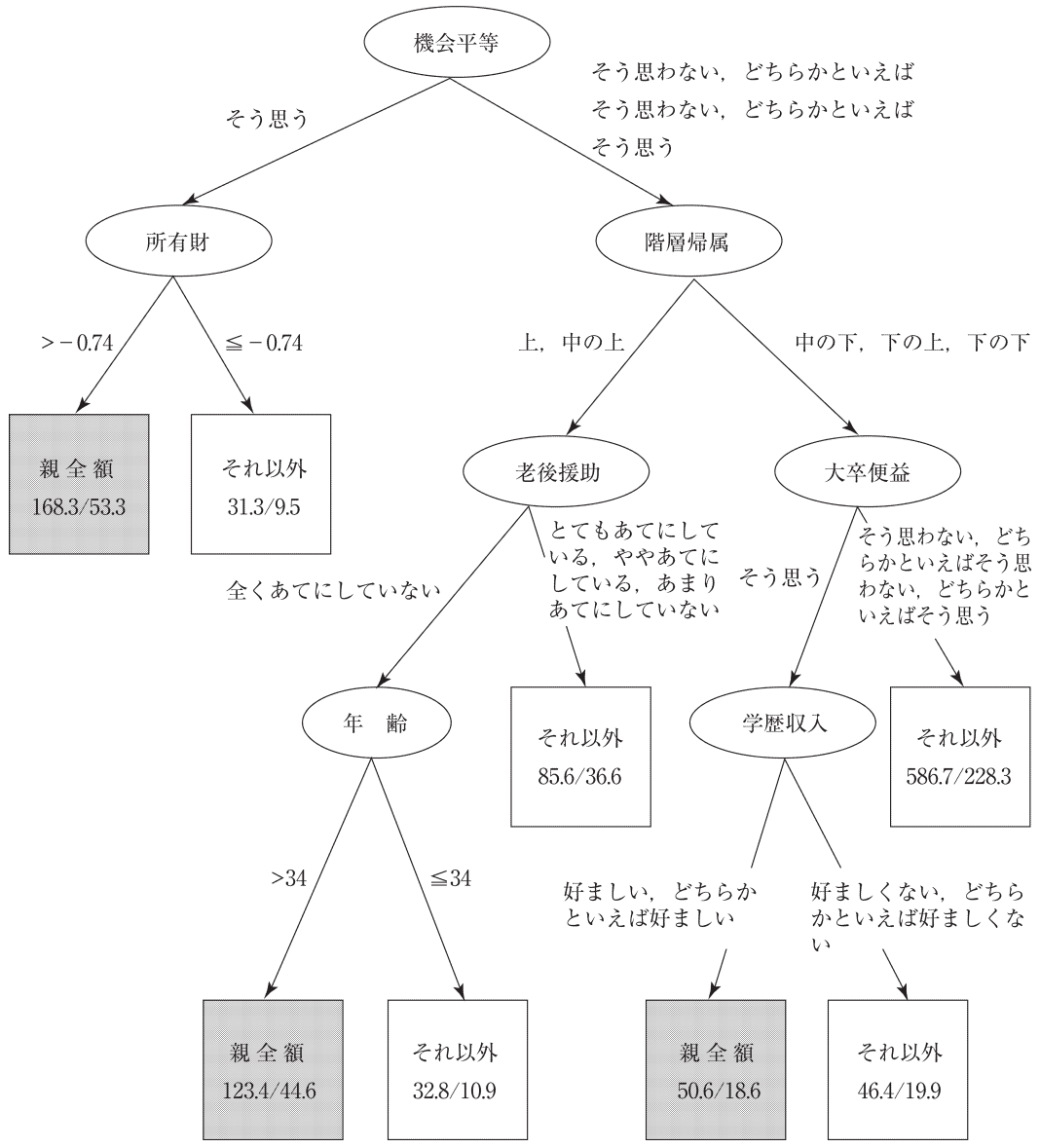

アが小さければ，親が全額負担すべきという意識は弱まる。

以上のような，根ノードから左に進んだケースに着目すると，「親全額」とする割 合が大きい（「親全額」 124.5 人，「それ以外」 75.1 人 $\left.^{(6)}\right)$ 。ここからは，進学できる可 能性が開かれているならば，費用を負担すべきという，親としての意識を読み取る ことができる。こうした 2 変数のみの関連であれば，決定木ではなく，クロス表か ら容易に検討できる。しかし，とりわけ根ノードから伸びる右の枝に見られるよう な, 条件付き効果を発見することは難しく, その発見に決定木の利点があるから 
(Thomas and Galambos 2004, Billari et al. 2006)，これを実際に見てみよう。 根ノードから右に進む枝は，教育機会が不平等であると認識している人びとから 構成され，この方向に分割されたサブグループでは，「親全額」とする者のほうが少 ない（「親全額」 406.5 人，「それ以外」 519.0 人 $^{(7)}$ )。すなわち, 教育機会が不平等 であれば，積極的に教育費を負担しても進学できる可能性は限られており，親が負 担しても無駄であると認識している者が多くなると推察される。

右の枝に進んだ場合，次に階層㷌属意識によって分岐していることが分かる。階 層帰属意識が「上」あるいは「中の上」と比較的高ければ，老後の援助を期待して いるかどうかを示す変数が，次のポイントとなる。このとき，子どもの援助を期待 していれば，親が負担すべきという意識は弱いことが示される。この結びつきは， 子どもからの経済的援助に頼るつもりでいる一方で, 子どもに教育費を援助しよう とする意識は薄いという，利己的な意識であると解釈できる。子どもの援助をあて にしていない場合，意識は年齢で分岐するが，特に，教育費を実際に負担している と予想される年齢層（34歳以上）では，老後の生活設計に，子どもの経済的援助を あてにしないにもかかわらず，「親全額」と分類される ${ }^{(8)}$ 。これは，見返りを期待せ ずに教育費を負担する親としての態度を反映している。

根ノードから右の枝に進んだケース数に着目すると，全体的には教育費負担に消 極的な態度を持つ者が多かったが，階層帰属意識が高い場合は，教育費負担に積極 的な者が相対的に多い(「親全額」 126.3 人，「それ以外」 115.5 人 $\left.^{(9)}\right)$ 。この部分木 (sub -tree）では, 教育を地位達成の手段とみなすような, 便益に関する変数は現れず, また特に見返りを期待していない場合, 子どもの教育のために費用を負担しようと する意識も高くなる。これらのことから，階層㷌属意識の高いグループには，教育 の地位表示機能を重視する人が多いと推察される。

一方で，階層帰属意識が低い場合(「中の下」「下の上」「下の下」)，教育が地位や 収入を得るための手段として認識されているか否かが，重要なポイントとなる。つ まり，大卒学歴と高い地位や収入が結びついているという認識が弱ければ，即座に 「それ以外」に分類される。しかし，大学の効用を認識しており，かつ学歴が高い人 ほど収入が高い状況に肯定的である者は, 親負担に対しても肯定的な立場を取る。 このように，階層帰属意識が比較的低いグループでは，大卒学歴が地位や収入と結 びつくならば，費用を負担して教育を受けさせたいという，教育費負担の投資的な 側面が見て取れる。また，階層に関係する変数の中でも客観的変数ではなく，主観 的な階層帰属意識によって分岐していることからは，自身の地位を低く認識してい 
るからこそ，教育が社会移動の手段であれば，これを利用したいという意識である と解釈できる。このように，階層帰属意識から伸びる枝の左右で，教育費負担意識 に関係する要因が，一方で消費的側面，他方では投資的側面であり，明確に分かれ ている。

以上のような教育を求めるパターンとは対照的に，教育費負担意識が「それ以外」 の最も多い葉に着目すると, 教育機会は不平等であり, かつ自身の社会階層上の位 置も低いのに加えて, よい大学を卒業したとしても, 高い地位や収入に結びつくわ けではないという認識パターンである。これは, 教育を通じた社会移動に期待せず, 教育自体に意味を見出さない層であるといえる。

木の全体に目を向ければ，決定木に現れた変数は多くが意識変数であり，とりわ け教育に関する意識変数が多い ${ }^{(10)}$ 。そのうえ, 多様な変数群を投入したにもかかわら ず，意識変数間のパターンが簡潔に与えられており，教育費負担の動機として，整 合的な解釈が可能になっている。先に, 決定木にまったく現れない変数もあり，そ のような変数は, 従属変数を予測する際には考慮されないことを述べた。客観的変 数は, 木の末端に現れる程度で, 学歴や職業などの階層変数は決定木に現れていな い。これは，すべての変数を同時に考慮すれば，決定木に現れた意識変数と比べて， 階層変数が教育費負担意識とそれほど強く関連していないということである。した がって, 学歴や職業によって教育費負担に対する意識が大きく異なるのではないこ とを示唆している。

\section{3. 意識変数の効果}

前節では，教育費負担意識を基準にした決定木を用いて，たくさんの変数との関 係を探索的に分析してきた。この結果, 図 1 の決定木により全体のサンプルでは, 従属変数に対して,「機会平等」という状況認識の効果が最も強く,さらにこの「機 会平等」に対する回答によって，サブグループに分割すると，教育機会が不平等で あると認識している人のグループでは, 階層帰属意識が, 教育費負担意識の分化に 関係していることが発見された。このように決定木は, それぞれのサブグループに おいて, 従属変数に対して最も影響力のある変数を発見するけれども, それは, 例 えば重回帰分析のような，他の変数の影響を統制したときの効果ではない。このた め，決定木にはほとんど現れなかった客観的変数をコントロールすれば，意識変数 の効果がほとんど見られなくなる可能性がある。このことから，決定木によって捉 えられた，「機会平等」「階層帰属」「大卒便益」の 3 つ意識変数の効果が, 客観的 
変数を統制したときに見られるかどうかを検証する。これらの意識変数を取り上げ れば，教育機会が不平等であるとの認識のもとで，消費と投資の側面が教育費負担 意識と関連するというパターンの有効性を確かめることができるだろう。

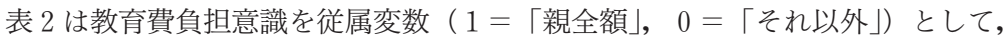
ロジスティック回帰分析を行った結果である。この分析で用いた客観的変数の值は, 表 1 と同様であるが， 3 つの意識変数は決定木によって示された区分を利用して, ダミー変数として投入した ${ }^{(11)}$ 。さらにここでは, 全サンプルの結果と, 決定木によっ て分割された各サブグループの結果を別々に示している。

\section{表 2 ロジスティック回帰分析の結果}

\begin{tabular}{|c|c|c|c|c|c|c|}
\hline & \multicolumn{2}{|c|}{$\begin{array}{l}\text { 全サンプル } \\
(\mathrm{N}=1051)\end{array}$} & \multicolumn{2}{|c|}{$\begin{array}{c}\text { サブグループ } 1 \\
(\mathrm{~N}=830)\end{array}$} & \multicolumn{2}{|c|}{$\begin{array}{c}\text { サブグループ } 2 \\
(\mathrm{~N}=604)\end{array}$} \\
\hline & $\beta$ & $\exp (\beta)$ & $\beta$ & $\exp (\beta)$ & $\beta$ & $\exp (\beta)$ \\
\hline 切片 & $-1.075^{* *}$ & 0.341 & $-1.034^{* *}$ & 0.356 & $-0.902^{*}$ & 0.406 \\
\hline 性別（1＝男性， $0=$ 女性） & -0.117 & 0.890 & -0.031 & 0.962 & -0.027 & 0.973 \\
\hline 年齢 & $0.018^{* *}$ & 1.019 & $0.016^{*}$ & 1.015 & 0.008 & 1.008 \\
\hline $\begin{array}{l}\text { 結婚（ } 1=\text { あり，0=なし） } \\
\text { 学歴（高校） }\end{array}$ & 0.072 & 1.075 & 0.085 & 1.089 & 0.376 & 1.457 \\
\hline 中学 & $-0.427^{*}$ & 0.652 & -0.258 & 0.773 & -0.264 & 0.768 \\
\hline 高等 & $0.249 \sim$ & 1.283 & 0.184 & 1.203 & -0.015 & 0.985 \\
\hline 職業（ブルーカラー） & & & & & & \\
\hline 専門管理 & 0.116 & 1.123 & 0.165 & 1.179 & 0.302 & 1.352 \\
\hline 事務販売 & -0.229 & 0.795 & -0.253 & 0.777 & -0.344 & 0.709 \\
\hline 無職 & -0.105 & 0.900 & -0.117 & 0.890 & -0.298 & 0.742 \\
\hline $\begin{array}{l}\text { 機会平等 } \\
(1=\text { そう思う, } 0=\text { それ以外 })\end{array}$ & $0.737^{* *}$ & 2.089 & & & & \\
\hline $\begin{array}{l}\text { 階層帰属 } \\
(1=\text { 上/中の上, } 0=\text { 中の下〜下の下 })\end{array}$ & & & $0.416^{*}$ & 1.517 & & \\
\hline $\begin{array}{l}\text { 大卒便益 } \\
(1=\text { そう思う， } 0=\text { それ以外 })\end{array}$ & & & & & $0.538^{*}$ & 1.712 \\
\hline
\end{tabular}

注） 各変数の（）は基準カテゴリーを示す。

表 2 からは，全サンプルの結果では，学歴や職業を統制したうえでも意識変数の 効果を確認できる。繰り返しになるが，教育機会が平等であると認識していれば, 教育費負担における親の役割を重視するということである。また，階層変数の効果 については, 高卒者に比べて中卒者は, 負担の意欲が弱いことが示されているが, 職業による意識の違いは確認できない。次に, サブグループ 1 は, 教育機会が不平 等であると認識している者のグループに対する結果である。決定木では，階層帰属 
意識が重要であることが示されたが，その効果は，他の変数を統制しても，依然と して認められる。つまり，自身の所属階層が比較的高いと認識していれば，子ども の教育に対する意欲も高くなるのである。さらに, サブグループ 2 は, 教育機会を 不平等と認識し，かつ階層帰属意識が低いグループに対する結果である。上の結果 と同様に，他の変数を統制したうえでも，決定木に示された意識変数(「大卒便益」) の効果は認められ, よい大学を卒業することが高い地位や収入に結びつくと認識し ている方が，親負担に肯定的であることが分かる ${ }^{(12)}$ 。

以上, 客観的変数を考慮してもなお, 決定木に現れた意識変数の効果があるかど うかを検証した。学歴や職業に関して, 決定木ではノードに現れなかったが,これ は，サンプルを分割するどの局面においても，それらの変数より意識変数のほうが 重要であることを示唆していた。これに対して，全サンプルにロジスティック回帰 分析をあてはめた場合, 高卒者に比べて中卒者の負担意欲が弱いことが示されてお り, 確かに階層変数の効果が全くないとは言えない。しかし，ここで注目すべきな のは, 客観的変数を統制しても, 決定木によって発見された意識変数の効果が認め られた，ということである。したがって，教育機会が不平等であるという認識のも とで，投資や消費の意識が教育費負担意識に影響することが明らかとなり，決定木 に示されたパターンの有効性が改めて確認されたのである。

\section{4.まとめと考察}

本稿では, 親の熱心な教育費負担を意識面から追究してきた。はじめに, 教育, 社会状況の認識や社会的特徵に応じて, 投資や消費などの教育費負担動機が異なる 可能性を指摘した。こうした複雑な意識を読み解くことを目的として, データマイ ニング手法の 1 つである決定木を用いて，教育費負担意識を従属変数とした探索的 な分析を行った。

まず，全般的な傾向からは，依然として親が教育費を負担すべきという認識が強 く，子どもの教育費用を親の責任とみなす意見が多い。親が子どもの教育費を負担 する理由として, 教育経済学や教育社会学の議論が, 最も注目してきたのは, 高い 所得や社会的地位を得るための投資的側面であった。そのように，いかなる状況に おいても，投資的側面が重視されるとすれば，決定木の根ノードに便益の認識が現 れるはずである。しかし，実際の根ノードに現れたのは，教育の便益に関する変数 ではなかった。これは, 意識をパターンとして見ることの有効性を示唆するもので ある。 
決定木のパターンによれば，投資的な動機が特に強く見られるのは，教育機会が 不平等であり，かつ自身の階層的地位が低いという状況認識を持つグループにおい てである。つまり,このグループでは, 教育を社会的地位や所得を得る手段として 認識していれば，教育費を負担しようとする意識につながるわけであるが，全体か ら見れば，投資としての意味合いは局所的なものであるといえる。また，教育機会 が閉ざされていると認識し，かつ階層帰属意識の高いグループにおいては，相対的 に負担意識が強く消費的動機を重視すると解釈できるから, 社会状況の認識によっ て，教育費負担動機が異なると考えられるのである。

これらのパターンが示すのは，教育機会の閉鎖性を認識したグループで，投資や 消費の認識が，負担意欲を高めるということである。これは，社会状況の認識に対 応して, 教育費負担動機が形成されていることを示す。つまり, 教育機会が閉ざさ れていると認識していれば, 教育費を負担したとしても, 子どもが進学できる可能 性は限られており, 教育費負担に意味を見出すことが困難となる。その状況で, 投 資であれ消費であれ，なんらかの便益がなければ，教育費負担に積極的な意味を見 出すことは難しい。そうした意味を見出してこそ, 教育費を工面するということで ある。

一方で，決定木の根ノードは，教育機会の認識であったが，機会が開かれていれ ば，教育費負担に意欲的であることを示していた。教育機会が平等であるというこ とは, 学歴取得が, 誰にでも参加できる競争状態にあると認識していることを意味 する。そして，多くの者が進学する状況でそのような認識があれば，競争を煽られ るために教育費を惜しまず負担し, 子どもを進学させようという意識を持つと推察 される。

このとき，決定木においてもそうであったように，投資的動機が前面に現れるわ けでない。このことを考えるにあたつて，竹内（1995，1996）の議論が参考になる だろう。竹内は, 細かな学校ランクによって序列化されている傾斜的選抜システム において, 多くの者が, 可能性のある進学先に向けて競争意欲を焚きつけられるが, その潜在的カリキュラムは,「なにになるかや, 何をするかの遠い未来の野心を背後 に退かせ，目前の選抜のことにだけ注意を集中させる」（竹内 1996, p. 60) と述べ ている。同様に, 親も子どもの教育機会が開かれていると認識すれば, 子どもの進 学に向けて教育費を支出しょうとする意欲が高まりつつも, 投資的動機は後退する と考えられるのである。加えて, 根ノードから左に進んだとき, 所有財に関する変 数によって分岐していたが，財を多く消費している人ほど，教育費負担意識も高か 
つた。このことから, 教育機会が開かれているという状況認識のもとでは, 教育費 負担動機が，投資か消費のどちらかといえば，消費的側面に近いということかもし れない。

以上のような教育需要の動機構造を確認できるが，教育に積極的な関与を示さな い者にも目を向けておこう。1995年 SSM 調査の分析では, 階層再生産のために教育 をクールに利用する層と，手段的にも教育に意味を見出さない層の分化が指摘され ているが (本田（沖津）1998)，決定木に示されたパターンによれば，教育費負担に 消極的な者が最も多いのは，教育機会は不平等であり，自身の社会階層上の位置も 低く，よい大学を卒業したとしても，高い地位や収入に結びつかないという認識パ ターンであった。したがって，教育に関与しようとしない層が，単に教育に手段的 意味を見出していないだけでなく, 教育機会の見通し，社会階層の観点からみた自 身の状況も厳しい状態にあると認識していることが分かる。このように，意識のパ ターンを検討することで，教育に関与しようとしない層についても，教育費負担の 意味づけをより具体的に捉えることができるのである。

さらに，こうした意識変数の効果は，客観的変数を統制したうえでも，確認され た。一方，学歴は教育費負担意識に影響を及ぼしていたが，職業によって意識が大 きく異なるという傾向は，どちらの分析でも見られなかった。この結果に関しては， 例えば，加熱した小学校受験が資源を多く有する一部の親に担われている事実（小 針 2004）などを考慮すれば，違和感があるかもしれない。しかし，本稿で検討し たのは教育費一般に対する意識であり，また教育費負担に関して，所得が低くても 親が積極的に負担し，このことが教育機会の格差をそれほど大きく広げないことに 貢献しているという見方もある(小林 2005)。逆に言えば，こうしたことが教育費 負担を非常に重くしているのである。低所得の家庭のほうが収入に占める教育費割 合は大きくなるから(例えば，都村 2006)，今後教育費負担の重さが，人びとの機 会認識にストレートに反映され，家庭の経済状態によって教育機会が閉ざされてい ると考える者が多くなれば，教育費を積極的に負担しようとしない層が増加するこ とも予想される。

最後に，今後の課題を述べておきたい。まず，図 1 の決定木に関して，誤分類の 割合を算出すると, この值が比較的大きかった。具体的には, 決定木に分類された ケースのうち，37.3\%が詋って分類されたということが分かった。誤分類が大きい 理由の 1 つとして, 教育費負担の動機について, 投資や消費では捉えられない面が 残されていると考えられる。次に, 決定木によって示された意識パターンから, 教 
育費支出の動機構造を読み取ることができたけれども，こうしたパターンが実際の 教育費負担にどう関与しているかについては，データの制約上明らかにできない。 これらの点については, 新たなデータの収集が必要であり, 今後の課題としたい。

【付記】データの使用については2005年社会階層と社会移動調査研究会の許可を得 た。

\section{〈注〉}

（1）このほかにも，子どもの教育に対する意識を検討した実証分析では，地位形成 機能から見た学歴効用の認識との関連を扱った，阿部（1996）, 山口（1997）の研 究や, 学歴満足度との関連を検討した広島大学教育社会学研究室（1998）がある。

（2）逆に，状況認識や社会的特徵に関係なく，投資や消費の側面が重視されている とすれば，そのことを示すこともできる。

（3）質問紙では(1)回答者の親がどちらの考えに近かったか，(2)回答者自身が親の立 場であった場合はどちらに近いか，の２種類の質問を別々にしている。本稿の分 析では(2)の親自身の立場に対する回答を従属変数としている。

（4）計算方法はアルゴリズムによって異なり，情報量に基づいて分割させる Quinlan の C4.5 (Quinlan 訳書, 1995)や， $\chi^{2}$ 值を基準として分岐させる CHAID (Kass 1980）などがある。なお，本論では前者を用いた分析結果を報告しており，分析 にはWeka3.4を用いた。Weka（Waikato Environment for Knowledge Analysis）はニュージーランドの Waikato 大学で開発されたデータマイニングのソフ トウェアであり, http://www.cs.waikato.ac.nz/ml/weka からダウンロードでき る。Wekaに含まれるたくさんのプログラムのうち, J4.8はC4.5に若干の改良を 加えたものとされるが (Witten and Frank 2005)，J4.8とC4.5の 2 つの結果を 比較すると，誤分類されたケース数の表示方法が異なることが確認された。

（5）また，決定木の生成過程には，木が過度に複雑になることを防ぐために，枝刚 り (pruning) という過程が含まれる。これは, 木が過度に複雑なとき, 予測の誤 差が大きい末端の枝を刈り取ることである。サンプル数が多い場合, 決定木が過 度に複雑になる傾向があるが，これを調整するために，信頼度 (confidence) と葉 の最小ケース数をあらかじめソフトウェアに設定されたデフォルト值（順に $25 \%$ と 2 ケース）ではなく，それぞれ $20 \%$ と 25 ケスとした。このように，信頼度の 值を下げ，最小ケース数を大きくすることは，よりシンプルな決定木を生成する 
ことを意図している。

（6）ケース数の算出は次のとおりである。「親全額」= $(168.3-53.3)+9.5=124.5$ 。 $\lceil そ れ 以$ 外 $」=(31.3-9.5)+53.3=75.1$ 。例えば，「親全額」のケース数の場合, 「親全額」の葉のケース数から誤分類のケース数を引き，「それ以外」の葉の誤分 類ケースを加えている。

(7) ケース数の算出は次のとおりである。「親全額」=36.6+ $(123.4-44.6)+10.9+$ $228.3+(50.6-18.6)+19.9=406.5$ 。「れ以外」 $=(85.6-36.6)+44.6+(32.8-$ $10.9)+(586.7-228.3)+18.6+(46.4-19.9)=519.0$ 。

（8）この調査では，子どもの有無に関する項目がない。このため，35歳以上のサン プルを対象とした分析も行ったが，決定木全体として類似の傾向が確認された。 また, 結婚経験があれば子どもをもつ可能性が高くなるため, 決定木分析と後述 のロジスティック回帰分析の両方に，結婚に関する変数を投入したが，いずれの 分析でも，この変数の有意な効果は確認できなかった。

(9) ケース数の算出は次のとおりである。「親全額」= $36.6+(123.4-44.6)+10.9=$ 126.3 。「それ以外」 $=(85.6-36.6)+44.6+(32.8-10.9)=115.5$ 。

(10) $\chi^{2}$ 值を基準として決定木を生成する CHAID でも同様の分析を行ったが，類似 した決定木の構造が現れた。

(11) 例えば，「機会平等」については，「そう思う」を 1 ，「それ以外」(「そう思わな い」「どちららといえばそう思わない」「どちらかといえばそう思う」)を０として いる。

(12) 家計所得を独立変数として加えても, 所得の効果は有意ではなく, 全サンプル, サブグループ 1 の結果は，ほぼ同じであった。しかし，家計所得には欠損值が多 く，「大卒便益」に対して「そう思う」と回答した者が極端に少なくなったため, サブグループ 2 に関しては，意識変数の効果は統計的に有意ではなかった。だが, 家庭の経済状況の代理変数として「所有財」を用いると, サンプル数が確保でき, サブグループ 2 の分析においても，「大卒便益」の統計的に有意な効果が確認でき た。

\section{〈文献〉}

阿部晃士，1996，「高校生と両親の出世観——社会のしくみに関する認知・理念・不 公平感」鈴木昭逸・海野道郎・片瀬一男編『教育と社会に対する高校生の意識 一一第 3 次調查報告書』東北大学教育文化研究会, pp. 43-58. 
天野郁夫，1983，「教育の地位表示機能について」『教育社会学研究』第38集，pp. 44 -49 .

Ball, Stephen J., 2003, Class Strategies and the Education Market: The Middle Classes and Social Advantage, RoutledgeFalmer.

Berry, Michael J. A. and Gordon S. Linoff, 2004, Data Mining Techniques: For Marketing, Sales, and Customer Relationship Management 2nd Edition, Wiley Publishing (=2005, 江原淳 ・佐藤栄作 ・上野勉・朝稲努・河野順一 ・ 寺田栄治・斉藤史朗・谷岡日出男・藤本浩司共訳『データマイニング手法— 営業, マーケティング, CRM のための雇客分析 2 訂版』海文堂).

Billari, Francesco C., Johannes Fürnkranz and Alexia Prskawetz, 2006, “Timing, Sequencing, and Quantum of Life Course Events: A Machine Learning Approach", European Journal of Population, Vol. 22, No. 1, pp. 37-65.

Bourdieu, Pierre, 1979, La Distinction: Critique Sociale du Jugement, Minuit. (= 1990，石井洋二郎訳『ディスタンクシオン I・II』藤原書店).

原純輔・盛山和夫，1999，『社会階層—豊かさの中の不平等』東京大学出版会。 広島大学教育社会学研究室, 1998, 「学歴意識に関する調査研究(1)」『教育社会学研 究年報』第 1 号, pp. 1-32.

本田 (沖津) 由紀，1998，「教育意識の規定要因と効果」苅谷剛彦編『教育と職業— 構造と意識の分析』(1995年 SSM 調査シリーズ11) 1995年 SSM 調査研究会, pp. 179-197.

苅谷剛彦，1995，『大衆教育社会のゆくえ——学歴主義と平等神話の戦後史』中公新 書。

Kass, G. V., 1980, “An Exploratory Technique for Investigating Large Quantities of Categorical Data”, Applied Statistics, Vol. 29, No. 2, pp. 119-127.

小針誠，2004，「階層問題としての小学校受験志向——家族の経済的・人口的・文化 的背景に着目して」『教育学研究』第71巻, 第4号, pp. 422-434. 小林雅之, 2005, 「教育費の家計負担は限界か一一無理する家計と大学進学」『季刊 家計経済研究』No. 67, pp. 10-21.

近藤博之・古田和久・川村光・愛知輝義, 2005 ,「ライフヒストリー・データの探索 的解析一一社会階層の文脈を探る」近藤博之編『ライフヒストリーの計量社会 学的研究』平成 $14 \sim 16$ 年度科学研究費補助金 [基礎研究(B)(1)] 研究成果報告書, pp. 1-22. 
中村高康, 2000,「高学歴志向の趨勢——世代の変化に注目して」近藤博之編『日本

の階層システム 3 戦後日本の教育社会』東京大学出版会, pp. 151-173.

2003年階層調査研究会，2004,『2003年仕事と暮らしに関する全国調査 コードブッ

ク・基礎集計表』2003年階層調査研究会。

小塩隆士，1999，「消費としての教育」八代尚宏編『市場重視の教育改革』日本経済

新聞社, pp. 47-72.

一，2002，『教育の経済分析』日本評論社。

Quinlan, Ross J., 1993, C4.5: Programs for Machine Learning, Morgan Kauf-

mann Publishers (=1995, 古川康一監訳『AIによるデータ解析』トッパン).

末冨芳，2005，「教育費スポンサーとしての保護者モデル再考一一高校生・大学生保

護者質問紙の分析から」『教育社会学研究』第77集, pp. 5-25.

竹内洋, 1995, 『日本のメリトクラシー——構造と心性』東京大学出版会.

—, 1996, 「大衆受験社会と学卒労働市場——対応と摇らぎ」『日本労働社会

学会年報』第 7 号, pp. 53-69.

Thomas, Emily H. and Nora Galambos, 2004, "What Satisfies Students?: Mining

Student-Opinion Data with Regression and Decision Tree Analysis"

Research in Higher Education, Vol. 45, No. 3, pp. 251-269.

豊田秀樹, 2001, 『金鉱を掘り当てる統計学——゙ータマイニング入門』講談社ブ ルーバックス。

都村聞人，2006，「教育費負担に影響を及ぼす諸要因— JGSS-2002データによる

分析」大阪商業大学比較地域研究所・東京大学社会科学研究所編『日本版 Gen-

eral Social Surveys 研究論文集 [5]』, pp. 135-148.

山口洋，1997，「学歴に関する社会イメージと子どもに対する教育期待」『金沢大学

文学部論集 行動科学・哲学篇』第17号, pp. 61-81.

Witten Ian H. and Eibe Frank, 2005, Data Mining: Practical Machine Learning

Tools and Techniques 2nd Edition, Morgan Kaufmann Publishers. 
ABSTRACT

\title{
The Structure of Motives for Educational Expenditures: Decision Tree Analysis of Attitudes toward Education.
}

\author{
FURUTA, Kazuhisa \\ (Graduate School, Osaka University) \\ 1-2 Yamadaoka, Suita-shi, Osaka, 565-0871, Japan \\ E-mail: furuta@ hus.osaka-u.ac.jp
}

This paper examines the impact of social class and a variety of attitudes regarding society and education on attitudes toward educational expenditures. In Japan, the rapid rise of educational participation rates has been strongly supported by household expenditures. The scale of private funding is very large in comparison with other countries, and not only high income parents, but also low income ones, make expenditures for their children's education. Therefore, the following question arises: what motivates Japanese people to give education to their children? Previous research on economics and the sociology of education has focused on investment and consumption. However, considering that the motives for educational expenditures are complex and are influenced by a variety of characteristics of parents, including attitudes on society and education, this paper investigates attitudes toward educational expense using data from the 2003 National Survey on Work and Daily Life. In order to identify significant patterns in many variables, decision tree analysis is used as a data mining techniques.

Following a brief introduction of decision tree analysis, the technique is applied to delineate the key features that distinguish between people who are eager to pay their children's educational expenses and those who are not. First, the data indicate that many people believe that parents should pay for nearly all of their children's educational costs. Second, decision tree analysis reveals that the most important factor influencing the payment of educational expenses is not the benefit of education, but rather the recognition of educational inequality in contemporary Japanese higher education. People who perceive educational opportunities as being equal are more willing to pay for their children, because they believe that there is stiff competition for educational credentials. Third, investment and consumption are important factors for people who believe there is educational inequality. As a result, the motive for making educational expenditures depends on attitudes toward society and education.

On the other hand, the group that showed most strongly negative attitude is people who believe that educational opportunities are closed by family income and that their own subjective social status is low, and that education does not play a central role for achieving high income and social status. This finding suggests that at present, educational costs are very heavy, and that if the burden of tuition fee and other educational expenses clearly brings an awareness of educational inequalities according to family income, many people will perceive education as being meaningless for them. 